\title{
The influences of smartphones on students' learning outcomes: A case study perspective
}

\author{
Basil Alzougool $^{\mathrm{a}}$ and Jarrah Al-Mansour ${ }^{\mathrm{a}^{*}}$
}

\begin{tabular}{l} 
aArab Open University, Kuwait \\
\hline C H R O N I C L E \\
\hline Article history: \\
Received: April 20, 2020 \\
Received in revised format: May \\
27, 2020 \\
Accepted: May 27, 2020 \\
Available online: June 1,2020 \\
\hline Keywords: \\
Smartphone Use \\
E-Learning Management \\
Education \\
Students \\
Kuwait
\end{tabular}
\begin{abstract}
A B S T R A C T
Although e-learning management-related research has been pursued in many parts of the world, there is dearth of research that integrates this concept with the increasing trend of smartphone usage for educational purposes. Furthermore, research in the area shows a general lack of contextualizing the concept in the Middle Eastern context. Therefore, the aim of this study is twofold: (i) to explore the everyday use and role of smartphones among university students in Kuwait; and (ii) to identify if there are any socio-demographic differences in smartphone usage among university students. A questionnaire was completed by 376 students in order to achieve the study objectives. The results showed that students frequently used their smartphones at home and that they sometimes used these phones in recreation places and on transportation, at university, and when walking. Also, they always used their smartphones to complete fourteen non-learning activities, such as making phone calls, using it as a watch and as an alarm clock, and ten learning activities, such as checking their exam schedules, checking class timetables, and checking their grades. Moreover, social networking, learning, privacy, and safety were important reasons offered by students for owning/using smartphones. Furthermore, the study found that at least one of eight socio-demographic variables (i.e., gender, marital status, major/subject, nationality, smartphone brand, using it for the first time, age range, and level of study) has an effect on at least one pattern of smartphone usage. Several recommendations were made based on these findings that may improve the effectiveness of smartphone usage among university students in Kuwait.
\end{abstract}

\section{Introduction}

The smartphone is, today, a cornerstone of people's lives. A smartphone is a mobile phone running a complete operating system in a manner similar to a traditional computer, which offers advanced computing abilities and connectivity options in addition to traditional mobile functions. These features enable new kinds of mobile services that in turn shape the usage habits of smartphone users. Smartphones help users to complete various activities such as sharing information, sending and receiving emails, chatting, opening and editing documents, paying for products, learning, browsing and shopping. As smartphones provide various applications that address an increasingly wider range of usage situations, they have become increasingly integrated into people's everyday lives. Understanding smartphone usage patterns and characterizing how users access their mobile devices during their everyday lives have been active areas of research in recent years. For instance, Cui and Roto (2008) found that the main use of smartphones was task-oriented, addressing the goals of information seeking, communications, online transactions, and managing personal information. Equally, Falaki et al. (2010) studied the usage patterns of mobile phones; they found that there were similarities in the fine-grained usage patterns of users (e.g., the session time distribution). In a similar vein, Bohmer et al. (2011) found that users typically spent almost one hour per day on smartphones, and * Corresponding author.

E-mail address: jarrah@aou.edu.kw (J. Al-Mansour)

(C) 2020 by the authors; licensee Growing Science, Canada. doi: $10.5267 /$ j.ijdns.2020.6.002 
that the average duration of a given session on them was less than one minute. A noteworthy remark by Oulasvirta et al. (2012) states that the use of mobile devices might lead to the development of a checking habit that involves brief and frequent content consumption (e.g., checking emails and Facebook updates). On the other hand, smartphones are known to be very popular among university students, increasing their social inclusion and connectedness as well as providing a sense of security as they can contact others in times of distress or emergency (Balakrishnan \& Raj, 2012). Although most students do not own their smartphones for learning purposes, smartphone usage can nevertheless be directed towards useful and beneficial purposes. The smartphone has the potential to transform the traditional classroom into a new form of classroom which offers both tutors and students remote access to teaching and learning materials anywhere and anytime. For instance, Mohtar et al. (2013) found that university students in Malaysia had considered smartphones to be vital for learning at higher learning institutions. Students used smartphones to share notes between classmates, record lectures, as well as to take pictures of assignments for future reference and to share exam results on Facebook. Kim and Altmann (2013) also found that, generally speaking, each student had around 80 applications on his/her smartphone, and $16 \%$ of the applications were used for some kind of learning. Moreover, Payne et al. (2012) explored the usage of smartphones among medical students in the United Kingdom and found a high level of smartphone ownership, where participants endorsed the development of more applications to support medical students. Furthermore, Uys et al. (2012) found that students spent an average of five hours per day on their smartphones, interacting with others via social networking sites, and remained online for about 16 hours per day. In addition to the benefits of using a smartphone, there are also potentially negative effects on both users and the environment such as disruption of social interactions, sleep deprivation and attention deficit issues (Murdock, 2013).

\section{Smartphones within the Academic Arena}

In the academic environment, smartphones enable students to make use of applications whose characteristics make the smartphone a suitable option for them. According to Cohen (2011), these characteristics include, but are not limited to: (i) a wide range of content formats (e.g., text, image, video, etc.) and allow a combination of more than one form of content; (ii) allowing communication to take place in real time and to cross one or more applications through social sharing, email and feeds; (iii) involve different levels of interactions by participants who can create and comment on social media networks; and (iv) offer one-to-one, one-to-many and many-to-many communications. Therefore, smartphones enable students to easily interact and communicate with their family, friends, classmates, tutors, and other social groups. It was evident that smartphones are used to help achieve academic success in Western society (i.e., Mok et al., 2014; Kibona \& Mgaya, 2015; Olufadi, 2015), and indeed for leaning purposes (Lee et al., 2015). Integrating smartphone uses in the learning and education process represents a form of digital practice. In this regard, Fu et al. (2018) recommended the use of digital portfolio practices as they provide a remarkable direction for creating new processes that complement existing systems in communicating student learning and support competency-based curriculum. Although the use of smartphones and other digital practices are increasing in the academic environment, not all students use such platforms with the same level. For instance, Mukorera and Nyatanga (2017) found in their study that students in their first-year tend to be solitary learners and prefer teaching and learning practices that comprise one-on-one interaction with their tutor. They also found that students in their second-year tend to be more social learners, preferring teaching and learning practices that are in a group setup. Contrary to its benefits in academic use, smartphones may at the same time harm students in the instance of negative uses. For instance, it may encourage students to disengage from class activities, allow them to cheat in exams, discourage them from studying, and affect their general academic appraisal (Roberts et al., 2014). Smartphones was also found to negatively affect students' GPA (Samaha and Hawi, 2016). Having various characteristics and uses available for smartphone users, it becomes more likely that people in general will develop habitual or addictive smartphone behaviours (van Deursen et al., 2015). Such phenomena might also negatively affect the non-learning outcomes for university students in particular. The overuse of smartphones might force students into forms of habitual checking which may eventually push them into compulsive usage or forced addiction (Lee et al., 2014). Furthermore, the overuse of smartphones for non-learning purposes may lead to various health disorders including severe life stress (Thomee et al., 2011), as well as physical and mental health problems (Park \& Park, 2014; Hadlington, 2015). Although studies of patterns of smartphone usage among people, especially university students, have been conducted in many countries, but to the best of our knowledge very few have been conducted in the context of the Middle East - Kuwait in particular - yet none of these studies focusses on trends in smartphone usage among university students in general and students based on Kuwait in particular. Although the call of research on smartphone usage has been acknowledged (for instance, van Deursen et al., 2015; Demirci et al., 2015; Gökçearslan et al., 2016; Jung et al., 2016; Lopez-Fernandez, 2017; Elhai et al., 2017; Carvalho et al., 2018; Wolniewicz et al., 2018), most of relevant research is limited to descriptive behaviour (Yu et al., 2013). Therefore, this study will endeavour to explore two main objectives. First, it will consider how university students use their smartphones, and secondly it will investigate whether there any differences in smartphone usage patterns among university students in terms of their demographic and social background variables. In order to facilitate this investigation, several questions need to be addressed including, for instance, where do they use their smartphones, how do they use their smartphones for non-learning purposes, do they use their smartphones for learning purposes and how, and why do they use a smartphone? What is the importance of these reasons?

This study therefore explores the everyday use and role of smartphones among university students. The study specifically looks at the following themes of smartphone usage: (i) places in which smartphones are used, (ii) usage of smartphones for learning 
and non-learning purposes, (iii) reasons for using smartphones and their importance, and (iv) demographic and social differences in smartphone usage among university students. This research chose the Arab Open University-Kuwait Branch (AOU) as the university in which to examine this phenomenon among university students.

\section{Method}

\subsection{Population and Sampling Technique}

Since this study is exploratory in nature, focussing on understanding how smartphones are used for both learning and nonlearning purposes, a quantitative approach was adopted. With a single case-based approach, 376 surveys were gathered from one private university in Kuwait. The questionnaire was used to obtain data from AOU students (Kuwait Branch) with regards to their use of smartphones. The use of questionnaire is probably one of the best methods available for the collection of original data that describes a large population without observing directly (Bryman, 2016; Saunders et al., 2016). The sample was from amongst students who are currently enrolled in AOU in different academic years, majors/subjects, genders, GPAs, and age groups. This choice was made due to the belief that the variation in these characteristics will fulfil the research enquires and consequently enrich the findings as students vary in terms of their maturity, uses of smartphones, and addiction level (Saunders et al., 2016). Furthermore, AOU is a multi-cosmopolitan university with many students from different nationalities, and this fact in itself forms a strong basis from which to obtain a realistic view of the current behaviour and uses of smartphones in the university. Thus, purposive as well as cluster sampling techniques were adopted as they are strongly associated with an easily accessible population rather than individual population members (Saunders et al., 2016). Additionally, purposive and cluster sampling techniques allow for a far greater geographical concentration than other quantitative sampling techniques (Bryman, 2016). The questionnaire was constructed by the researchers in this study, where questions were derived from the previous literature. Multiple choice and multiple selection questions were employed. Specifically, the questionnaire consisted of four complimentary parts, as follows:

(1) Part one consists of personal information (i.e., gender, age, marital status, education, and a question whether the participant owns a smartphone), and places of usage.

(2) Part two consists of questions about the use of the smartphone for non-learning purposes (e.g., social networking, calling, texting, etc.).

(3) Part three consists of questions about the use of the smartphone for learning purposes (e.g., logging in to the university portal, downloading and/or reading class materials, taking notes in a classroom, etc.).

(4) Part four consists of questions about the reasons for using the smartphone (e.g., socializing, safety, privacy, etc.).

The questionnaire was evaluated by a number of experts and distributed to students after making any necessary alterations as appropriate.

\subsection{Data Collection Procedure}

The fieldwork was carried out in Kuwait over a period of three months. The questionnaire was made available in in both English and Arabic to suit both national students as well as non-Arabic speakers. For validity purposes, copies in each language were reviewed by two experts to determine whether the questions reflected the same meaning in each instance (Hazzi and Maldaon, 2015). The questionnaire was distributed during regularly scheduled class sessions by the researchers with the help of other tutors, hence the drop off and pick up approach was used to collect the questionnaire in this research. This approach is a very commonly used and is an effective technique in the Kuwaiti context. The participants were given an explanation of the purposes of the study and asked to complete the questionnaire. The instructions for completing the questionnaire were also given on the cover page to avoid any misunderstandings. Students were assured of anonymity and confidentiality, and participation was entirely voluntary. Upon gaining the necessary approvals, the survey was piloted prior to the main distribution phase using 15 samples, and as a result some terms were clarified and two questions entirely removed. Furthermore, ethical clearance was granted prior the distribution of the questionnaire to comply with the research's ethical guidelines, and therefore participants were assured of anonymity. Data from the completed questionnaires was entered into a personal computer, which was then double-checked against the original questionnaires to ensure accurate data entry. The researchers also created a data codebook as a guide and reference point for later analysis. When data entry and checking was completed, statistical analysis was performed using SPSS version 23.0 for Windows. Descriptive statistics (e.g., frequencies, percentages, means, etc.) were employed to describe the characteristics of students who participated in the study. A series of variance approaches (e.g., ANOVA and T-test) were also employed to analyse the relationships between smartphone usage and the students' socio-demographic variables.

\subsection{Data Analysis and Findings}

The participants were given an explanation of the purposes of the study and asked to complete the surveys. In all, 500 surveys were administered to students, though only 376 surveys were returned and in a usable state in this study. A summary of the demographic characteristics of the respondents is presented in Table 1. More females (62.9\%) participated in the study than males $(37.1 \%)$. More than a third of participants $(39.1 \%)$ belonged to the 18 to 22 year-old age range, and more than quarter 
of them (27.3\%) belonged to the 23 to 27 year-old age range. The mean age of the participants in the study was 26.28 years. The majority of the respondents were single (74\%) and business students (78.9\%). Non-Kuwaiti students constituted more than half of the respondents (55.3\%), whilst more than two-thirds were enrolled in their $3^{\text {rd }}$ year of studies and above (67.9\%).

Table 1

Demographics of Participants

\begin{tabular}{|c|c|c|c|c|}
\hline Demographic & Categories & $\mathrm{No}=376$ & $\%$ & Missing \\
\hline \multirow{2}{*}{ Your Gender } & Male & 139 & 37.1 & \multirow{2}{*}{1} \\
\hline & Female & 236 & 62.9 & \\
\hline \multirow{4}{*}{ Age Range } & $18-22$ yrs & 142 & 39.1 & \multirow{4}{*}{13} \\
\hline & $23-27$ yrs & 99 & 27.3 & \\
\hline & $28-32$ yrs & 56 & 15.4 & \\
\hline & $33+$ yrs & 66 & 18.2 & \\
\hline \multirow{3}{*}{ Marital Status } & Single & 270 & $74 \%$ & \multirow{3}{*}{11} \\
\hline & Married & 84 & $23 \%$ & \\
\hline & Other & 11 & $3 \%$ & \\
\hline \multirow{2}{*}{ Nationality } & Kuwaiti & 165 & 44.7 & \multirow{2}{*}{7} \\
\hline & Non-Kuwaiti & 204 & 55.3 & \\
\hline \multirow{3}{*}{ Major } & Business & 296 & 78.9 & \multirow{3}{*}{1} \\
\hline & IT & 24 & 6.4 & \\
\hline & English & 55 & 14.7 & \\
\hline \multirow{4}{*}{ Year of Study } & 1st year & 28 & 8.1 & \multirow{4}{*}{30} \\
\hline & 2nd year & 83 & 24.0 & \\
\hline & 3rd year & 121 & 35.0 & \\
\hline & 4 th year \& above & 114 & 32.9 & \\
\hline
\end{tabular}

Table 2 contains answers to the descriptive questions that were used in the questionnaire. There were questions about whether students used Smartphone at all, the time when participants first started using a smartphone, the smartphone brand they used, and how often participants used their smartphones in various places. The results show that $99.5 \%$ of students reported they owned/used a smartphone. Of those, $60.2 \%$ and $30.7 \%$ stated that they owned/used and iPhone and Samsung, respectively, and that the majority of them (71\%) started using their smartphones for the first time five years or more ago. The results also showed that students always used their smartphone in their homes (76.4\%), and they sometimes used it at university (72.5\%), on public transportation $(66.2 \%)$, recreational places $(57.7 \%)$, and when walking $(54.7 \%)$ and driving $(48.5 \%)$.

Table 2

Descriptive Results Relating to Smartphone Usage by Respondent

\begin{tabular}{|c|c|c|c|c|c|c|}
\hline Descriptive questions & \multicolumn{3}{|c|}{ Categories } & $\mathrm{No}=376$ & $\%$ & Missing \\
\hline \multirow{2}{*}{ Do you own/use a smartphone? } & \multicolumn{3}{|l|}{ No } & 2 & 0.5 & \multirow{2}{*}{0} \\
\hline & \multicolumn{3}{|l|}{ Yes } & 374 & 99.5 & \\
\hline \multirow{6}{*}{ The time you first started using smartphone } & \multicolumn{3}{|c|}{ Less than one year } & 4 & $1.1 \%$ & \multirow{6}{*}{3} \\
\hline & \multicolumn{3}{|c|}{ One to less than 2 years } & 7 & $1.9 \%$ & \\
\hline & \multicolumn{3}{|c|}{ Two to less than 3 years } & 13 & $3.5 \%$ & \\
\hline & \multicolumn{3}{|c|}{ Three to less than 4 years } & 25 & $6.7 \%$ & \\
\hline & \multicolumn{3}{|c|}{ Four to less than 5 years } & 59 & $15.8 \%$ & \\
\hline & \multicolumn{3}{|c|}{ Five years and more } & 265 & $71 \%$ & \\
\hline \multirow{4}{*}{ The brand of your smartphone } & \multicolumn{3}{|c|}{ iPhone } & 218 & 60.2 & \multirow{4}{*}{14} \\
\hline & \multicolumn{3}{|c|}{ Samsung } & 111 & 30.7 & \\
\hline & \multicolumn{3}{|c|}{ iPhone \& Samsung } & 13 & 3.6 & \\
\hline & \multicolumn{3}{|c|}{ Other brands } & 20 & 5.5 & \\
\hline \multicolumn{2}{|c|}{$\begin{array}{l}\text { How often do you use your smartphone in the follow- } \\
\text { ing places? }\end{array}$} & $\mathbf{N}$ & $\begin{array}{c}\text { Never } \\
\text { Freq }(\%)\end{array}$ & $\begin{array}{l}\text { Sometimes } \\
\text { Freq }(\%)\end{array}$ & \multicolumn{2}{|c|}{$\begin{array}{l}\text { Always } \\
\text { Freq (\%) }\end{array}$} \\
\hline At home & & 373 & $2(0.5 \%)$ & $86(23.1 \%)$ & \multicolumn{2}{|c|}{$285(76.4 \%)$} \\
\hline At university & & 371 & $34(9.2 \%)$ & $269(72.5 \%)$ & \multicolumn{2}{|c|}{$68(18.3 \%)$} \\
\hline When driving & & 367 & $167(45.5 \%)$ & $178(48.5 \%)$ & \multicolumn{2}{|c|}{$22(6 \%)$} \\
\hline In transportation & & 367 & $51(13.9 \%)$ & $243(66.2 \%)$ & \multicolumn{2}{|c|}{$73(19.9 \%)$} \\
\hline Recreation places & & 366 & $51(13.9 \%)$ & $211(57.7 \%)$ & \multicolumn{2}{|c|}{$104(28.4 \%)$} \\
\hline When walking & & 369 & $89(24.2 \%)$ & $202(54.7 \%)$ & \multicolumn{2}{|c|}{$78(21.1 \%)$} \\
\hline
\end{tabular}

On the other hand, basic descriptive statistics such as frequency and percentage frequency distribution techniques were used to describe the use of smartphone for non-learning activities. There were 16 general activities listed in the questionnaire. Participants were asked to indicate how often they used their smartphones to perform these activities on a scale of one to three, where one indicated never and three indicated always. The frequencies and percentages of the students who chose the points on this Likert scale were calculated. Table 3 shows these activities as per the viewpoints of students who responded to the questionnaire. As shown in Table 3, the results indicated that students always used their smartphones to perform a number of activities such as making phone calls $(83.3 \%)$, using it as an alarm clock $(81.9 \%)$ and as a watch $(80.1 \%)$, chatting using social networking sites $(78.7 \%)$, taking pictures $(78.2 \%)$, browsing the internet $(77.3 \%)$, checking websites $(75.2 \%)$, checking and/or updating their profiles on social networking sites (69.8\%), downloading applications (66.3\%), checking email (65.2\%), recording videos $(62.8 \%)$, listening to music $(61.7 \%)$ and sending text messages $(61.1 \%)$. 
Table 3

Frequencies and Percentages of the Students Who Used their Smartphones to Do General (Non-Learning) Activities

\begin{tabular}{|c|c|c|c|c|}
\hline $\begin{array}{l}\text { How often do you use your Smartphone to do the following general (non-learning) } \\
\text { activities? }\end{array}$ & $\mathrm{N}$ & $\begin{array}{c}\text { Never } \\
\text { Freq }(\%)\end{array}$ & $\begin{array}{l}\text { Sometimes } \\
\text { Freq }(\%)\end{array}$ & $\begin{array}{c}\text { Always } \\
\text { Freq }(\%)\end{array}$ \\
\hline Making phone calls & 371 & $1(0.3 \%)$ & $61(16.4 \%)$ & $309(83.3 \%)$ \\
\hline Use it as an alarm clock & 371 & $13(3.5 \%)$ & $54(14.6 \%)$ & $304(81.9 \%)$ \\
\hline Use it as a watch & 371 & $4(1.1 \%)$ & $70(18.8 \%)$ & $297(80.1 \%)$ \\
\hline Chatting using social networking sites & 371 & $6(1.6 \%)$ & $73(19.7 \%)$ & $292(78.7 \%)$ \\
\hline Taking pictures & 371 & $6(1.6 \%)$ & $75(20.2 \%)$ & $290(78.2 \%)$ \\
\hline Browsing Internet & 371 & $4(1.1 \%)$ & $80(21.6 \%)$ & $287(77.3 \%)$ \\
\hline Checking websites pages & 371 & $2(0.5 \%)$ & $90(24.3 \%)$ & $279(75.2 \%)$ \\
\hline Checking and/or updating your profile on social networking sites & 371 & $21(5.7 \%)$ & $91(24.5 \%)$ & $259(69.8 \%)$ \\
\hline Downloading applications & 371 & $9(2.4 \%)$ & $116(31.3 \%)$ & $246(66.3 \%)$ \\
\hline Checking email & 371 & $13(3.5 \%)$ & $116(31.3 \%)$ & $242(65.2 \%)$ \\
\hline Recording video & 371 & $17(4.6 \%)$ & $121(32.6 \%)$ & $233(62.8 \%)$ \\
\hline Listening to the music & 371 & $43(11.6 \%)$ & $99(26.7 \%)$ & $229(61.7 \%)$ \\
\hline Sending text messages & 370 & $13(3.5 \%)$ & $131(35.4 \%)$ & $226(61.1 \%)$ \\
\hline Reading documents & 371 & $23(6.2 \%)$ & $175(47.2 \%)$ & $173(46.6 \%)$ \\
\hline Watching TV & 371 & $88(23.7 \%)$ & $166(44.7 \%)$ & $117(31.5 \%)$ \\
\hline Watching movies & 371 & $101(27.2 \%)$ & $142(38.3 \%)$ & $128(34.5 \%)$ \\
\hline
\end{tabular}

Moreover, participants were asked to indicate how often they used their Smartphones to perform 18 learning activities on a scale of one to three, where again one indicated never and three indicated always. The frequencies and percentages of the students who chose the points on this Likert scale were calculated. Table 4 shows these activities as per the viewpoints of students who responded to the questionnaire. As shown in Table 4, the results indicated that students always used their smartphones to do ten learning activities, namely checking exam schedules $(75.7 \%)$, checking class timetables (74.3\%), checking grades (72.4\%), logging in to the university portal (60.5\%), using blackboard (LMS) $(54.3 \%)$, using it to participate in the class learning groups (52.1\%), downloading class material (51.2\%), registering for courses $(49.7 \%)$, reading tutors' announcements (46.9\%), and making payment of fees $(41.1 \%)$; students sometimes also used their smartphones to perform six learning activities, namely taking photos of a class presentation (57.3\%), sending emails to tutors (46.6\%), using SIS $(45.6 \%)$, using e-library resources $(42.7 \%)$, processing various transactions related to students' services $(42.7 \%)$, and taking notes in the classroom (39.9\%); however, students never used their smartphones to both record a class lecture (56.6\%) or upload class assignments $(35.3 \%)$.

\section{Table 4}

Frequencies and Percentages of Students Who Used their Smartphones to Do Various Learning Activities

\begin{tabular}{|c|c|c|c|c|}
\hline How often do you use your smartphone to do the following learning activities? & $\mathrm{N}$ & $\begin{array}{c}\text { Never } \\
\text { Freq }(\%)\end{array}$ & $\begin{array}{c}\text { Sometimes } \\
\text { Freq }(\%)\end{array}$ & $\begin{array}{c}\text { Always } \\
\text { Freq (\%) }\end{array}$ \\
\hline Checking the exams schedule & 370 & $10(2.7 \%)$ & $80(21.6 \%)$ & $280(75.7 \%)$ \\
\hline Checking class timetable & 370 & $10(2.7 \%)$ & $85(23 \%)$ & $275(74.3 \%)$ \\
\hline Checking grades & 370 & $18(4.9 \%)$ & $84(22.7 \%)$ & $268(72.4 \%)$ \\
\hline Login to the university portal & 372 & $3(0.8 \%)$ & $144(38.7 \%)$ & $225(60.5 \%)$ \\
\hline Taking photos of a class presentation & 370 & $68(18.4 \%)$ & $212(57.3 \%)$ & $90(24.3 \%)$ \\
\hline Recording a class lecture & 369 & $209(56.6 \%)$ & $118(32 \%)$ & $42(11.4 \%)$ \\
\hline Using blackboard (LMS) & 372 & $27(7.3 \%)$ & $143(38.4 \%)$ & $202(54.3 \%)$ \\
\hline Using it to participate in the class learning groups & 370 & $48(13 \%)$ & $129(34.9 \%)$ & $193(52.1 \%)$ \\
\hline Downloading class material & 369 & $51(13.8 \%)$ & $129(35 \%)$ & $189(51.2 \%)$ \\
\hline Registering courses & 370 & $61(16.5 \%)$ & $125(33.8 \%)$ & $184(49.7 \%)$ \\
\hline Reading tutors' announcements & 371 & $48(12.9 \%)$ & $149(40.2 \%)$ & $174(46.9 \%)$ \\
\hline Sending emails to tutors & 371 & $83(22.4 \%)$ & $173(46.6 \%)$ & $115(31 \%)$ \\
\hline Using SIS & 371 & $36(9.7 \%)$ & $169(45.6 \%)$ & $166(44.7 \%)$ \\
\hline Using e-library resources & 370 & $150(40.5 \%)$ & $158(42.7 \%)$ & $62(16.8 \%)$ \\
\hline Processing students relating services transactions & 370 & $71(19.2 \%)$ & $158(42.7 \%)$ & $141(38.1 \%)$ \\
\hline Payment of fees & 367 & $106(28.9 \%)$ & $110(30 \%)$ & $151(41.1 \%)$ \\
\hline Taking notes in a classroom & 371 & $135(36.4 \%)$ & $148(39.9 \%)$ & $88(23.7 \%)$ \\
\hline Uploading class assignments & 371 & $131(35.3 \%)$ & $116(31.3 \%)$ & $124(33.4 \%)$ \\
\hline
\end{tabular}

In addition, participants were asked to indicate their reasons for owning/using smartphones on a scale of one to five, where one indicated not important and five indicated very important. The frequencies and percentages of the students who chose these points on the Likert scale were calculated. Table 5 shows these reasons as per the viewpoints of students who responded to the questionnaire. As shown in Table 5, the results indicated that social networking (85.5\%), learning (80.6\%), privacy $(70.6 \%)$, safety $(60 \%)$, freedom $(42.1 \%)$ and as a social status symbol $(39.2 \%)$ were the most important reasons for owning/using their smartphones. On the other hand, loneliness $(50.2 \%)$ and fashion $(47.4 \%)$ were the least important reasons for owning/using these phones. 
Table 5

Frequencies and Percentages of Reasons for Owning/Using Smartphones

\begin{tabular}{|c|c|c|c|c|c|c|}
\hline $\begin{array}{l}\text { How important are the following reasons for } \\
\text { owning/using a smartphone? }\end{array}$ & $\mathrm{N}$ & $\begin{array}{l}\text { Not Important } \\
\text { Freq }(\%) \\
\end{array}$ & $\begin{array}{l}\text { Slightly Important } \\
\text { Freq }(\%) \\
\end{array}$ & $\begin{array}{c}\text { Moderately Important } \\
\text { Freq (\%) } \\
\end{array}$ & $\begin{array}{l}\text { Important } \\
\text { Freq }(\%) \\
\end{array}$ & $\begin{array}{l}\text { Very Important } \\
\text { Freq }(\%) \\
\end{array}$ \\
\hline For Social networking & 372 & $3(0.7 \%)$ & $11(3 \%)$ & $40(10.8 \%)$ & $94(25.3 \%)$ & $224(60.2 \%)$ \\
\hline For Learning & 372 & $10(2.7 \%)$ & $10(2.7 \%)$ & $52(14 \%)$ & $109(29.3 \%)$ & $191(51.3 \%)$ \\
\hline For Privacy & 371 & $21(5.7 \%)$ & $30(8.2 \%)$ & $58(15.6 \%)$ & $94(25.3 \%)$ & $168(45.3 \%)$ \\
\hline For Safety & 372 & $30(8.1 \%)$ & $37(9.9 \%)$ & $82(22 \%)$ & $95(25.5 \%)$ & $128(34.5 \%)$ \\
\hline For Freedom & 370 & $71(19.2 \%)$ & $52(14.1 \%)$ & $91(24.6 \%)$ & $75(20.3 \%)$ & $81(21.8 \%)$ \\
\hline For Social status symbol & 370 & $70(18.9 \%)$ & $52(14.1 \%)$ & $103(27.8 \%)$ & $68(18.4 \%)$ & $77(20.8 \%)$ \\
\hline For Loneliness & 370 & $127(34.3 \%)$ & $59(15.9 \%)$ & $92(24.9 \%)$ & $36(9.7 \%)$ & $56(15.2 \%)$ \\
\hline For Fashion & 371 & $111(29.9 \%)$ & $65(17.5 \%)$ & $77(20.8 \%)$ & $53(14.3 \%)$ & $65(17.5 \%)$ \\
\hline
\end{tabular}

Two parametric tests - Independent samples T-test (t-test) and ANOVA techniques - were used because the scores of the dependent variables in this study were reasonably normally distributed. The T-test was conducted to look for significant differences in the four variables (usage of Smartphone for learning and non-learning activities, places and reasons for usage) in terms of six background variables (each of which had two distinct categories): gender; marital status, nationality; major/subject, using for the first time, and brand of smartphone. ANOVA was conducted between groups to explore whether there were significant differences between the four variables (usage of smartphone for learning and non-learning activities, places and reasons of usage) in terms of two background variables (each of which had more than two distinct or continuous categories): age range and level of study. The following scale is used to facilitate reporting the results:

- The smartphone was always used by students: calculated mean $(M \geq 2.3)$.

- The smartphone was sometimes used by students: calculated mean $(1.6>M<2.3)$.

- The smartphone was never used by students: calculated mean $(M \leq 1.6)$.

The following sections present the T-test and ANOVA results:

Table 6 illustrates the mean (M), standard deviation (SD), T-test and ANOVA of the use of smartphones by students in different places. When the frequently of reported places of usage were compared across the different categories of each of the eight socio-demographic variables, the following were found:

- Using a smartphone when driving varied according to student gender $(\mathrm{t}=2.016, \mathrm{p}=0.045)$ and marital status $(\mathrm{t}=-3.144$, $\mathrm{p}=0.002)$. Male students sometimes $(\mathrm{M}=1.69)$ used their smartphones when driving more than female students who never $(M=1.56)$ used them. Married students sometimes $(M=1.79)$ used their smartphones when driving more than single students, who never $(\mathrm{M}=1.55)$ used them. The use of a smartphone in any of the other places did not vary according to student gender or marital status.

- Using a smartphone in recreational places varied according to students' major/subject $(\mathrm{t}=2.062, \mathrm{p}=0.040)$. Business students sometimes $(\mathrm{M}=2.18)$ used their smartphones in recreational places more than non-business students $(\mathrm{M}=$ 2.01). The use of a smartphone in any of the other places did not vary according to students' majors/subjects.

- Using a smartphone at home $(\mathrm{t}=-3.075, \mathrm{p}=0.002)$, at university $(\mathrm{t}=-2.314-, \mathrm{p}=0.021)$, on public transportation ( $\mathrm{t}=$ 2.942, $\mathrm{p}=0.003)$ and when driving $(\mathrm{t}=2.242, \mathrm{p}=0.026)$ varied according to students' nationalities. Non-Kuwaiti students always used their smartphones at home $(\mathrm{M}=2.83)$, sometimes at university $(\mathrm{M}=2.15)$ and whilst on transportation ( $M=2.14)$ more than Kuwaiti students. However, Kuwaiti students sometimes $(M=1.69)$ used their smartphones when driving more than non-Kuwaiti student who never $(\mathrm{M}=1.55)$ used them in this manner. The use of smartphones in any of the other places did not vary according to student nationality.

- Using a smartphone when driving $(\mathrm{t}=-4.070, \mathrm{p}=0.000)$ and walking $(\mathrm{t}=-3.437, \mathrm{p}=0.001)$ and in recreational places $(\mathrm{t}$ $=-2.116, p=0.035)$ varied according to the use of the smartphone for the first time. Students who had their smartphones for five years or more sometimes used these phones when driving $(\mathrm{M}=1.69)$, walking $(\mathrm{M}=2.05)$ and in recreational places $(M=2.19)$ more than those who had had their smartphones for four years or less. The use of a smartphone in any of the other places did not vary according to using the smartphone for the first time.

- Using a smartphone at home $(\mathrm{F}=5.628, \mathrm{p}=0.001)$, at university $(\mathrm{F}=2.718, \mathrm{p}=0.045)$, on transportation $(\mathrm{F}=3.153, \mathrm{p}$ $=0.025)$ and when driving $(\mathrm{F}=4.069, \mathrm{p}=0.007)$ varied according to students' age range. Students who were aged between 18 and 22 always used their smartphones at home $(M=2.86)$, sometimes at university $(M=2.18)$ and on transportation $(\mathrm{M}=2.16)$ more than those who were in other age groups. However, students who were aged between 28 and 32 sometimes used their smartphones when driving $(\mathrm{M}=1.80)$ more than those in other age groups. The use of a smartphone in any of the other places did not vary according to students' age range. 
Table 6

Mean (M), T-test and ANOVA of socio-demographic variables of respondents for their scores on the places of smartphone usage

\begin{tabular}{|c|c|c|c|c|c|c|}
\hline How often do you use your smartphone in the following places? & Background variables & $\mathrm{N}$ & Mean & $\mathrm{SD}$ & $\mathrm{t}$ & $\begin{array}{l}\text { Sig. }(2 \\
\text { tailed) }\end{array}$ \\
\hline \multirow{8}{*}{ When driving } & Male & 135 & 1.69 & .604 & \multirow[b]{2}{*}{2.016} & \multirow{2}{*}{$.045^{*}$} \\
\hline & Female & 231 & 1.56 & .593 & & \\
\hline & Single & 261 & 1.55 & .590 & \multirow{2}{*}{-3.144} & \multirow{2}{*}{$.002 * *$} \\
\hline & Married & 84 & 1.79 & .603 & & \\
\hline & Kuwaiti & 163 & 1.69 & .604 & \multirow[b]{2}{*}{2.242} & \multirow{2}{*}{$.026 *$} \\
\hline & Non-Kuwaiti & 198 & 1.55 & .592 & & \\
\hline & Four years and less & 105 & 1.41 & .583 & \multirow{2}{*}{-4.070} & \multirow{2}{*}{$.000 * *$} \\
\hline & Five years and more & 261 & 1.69 & .589 & & \\
\hline \multirow[t]{4}{*}{ Recreation places } & Business & 288 & 2.18 & .621 & \multirow{2}{*}{2.062} & \multirow{2}{*}{$.040 *$} \\
\hline & Non-Business & 77 & 2.01 & .678 & & \\
\hline & Four years and less & 105 & 2.04 & .678 & \multirow{2}{*}{-2.116} & \multirow{2}{*}{$.035 *$} \\
\hline & Five years and more & 260 & 2.19 & .610 & & \\
\hline \multirow{2}{*}{ At home } & Kuwaiti & 164 & 2.69 & .477 & \multirow{2}{*}{-3.075} & \multirow{2}{*}{$.002 * *$} \\
\hline & Non-Kuwaiti & 202 & 2.83 & .379 & & \\
\hline \multirow[t]{2}{*}{ At university } & Kuwaiti & 164 & 2.02 & .495 & \multirow{2}{*}{-2.314} & \multirow{2}{*}{$.021 *$} \\
\hline & Non-Kuwaiti & 201 & 2.15 & .527 & & \\
\hline \multirow[t]{2}{*}{ In transportation } & Kuwaiti & 163 & 1.96 & .554 & \multirow{2}{*}{-2.942} & \multirow{2}{*}{$.003 * *$} \\
\hline & Non-Kuwaiti & 198 & 2.14 & .588 & & \\
\hline \multirow[t]{3}{*}{ When walking } & Four years and less & 106 & 1.78 & .602 & \multirow{2}{*}{$-3.437-$} & \multirow{2}{*}{$.001 * *$} \\
\hline & Five years and more & 262 & 2.05 & .688 & & \\
\hline & & & & & $\mathbf{F}$ & Sig. \\
\hline \multirow[t]{4}{*}{ At home } & $18-22$ years & 141 & 2.86 & .350 & & \\
\hline & $23-27$ years & 97 & 2.79 & .407 & & \\
\hline & 28-32 years & 56 & 2.64 & .520 & 5.628 & $.001 * *$ \\
\hline & $33+$ years & 66 & 2.65 & .480 & & \\
\hline At university & 18-22 years & 141 & 2.18 & .467 & & \\
\hline & 23-27 years & 95 & 2.01 & .574 & & \\
\hline & $28-32$ years & 56 & 2.05 & .401 & 2.718 & $.045^{*}$ \\
\hline & $33+$ years & 66 & 2.02 & .568 & & \\
\hline When driving & $18-22$ years & 139 & 1.52 & .594 & & \\
\hline & $23-27$ years & 94 & 1.54 & .562 & & \\
\hline & $28-32$ years & 55 & 1.80 & .650 & 4.069 & $.007 * *$ \\
\hline & $33+$ years & 66 & 1.71 & .576 & & \\
\hline In transportation & $18-22$ years & 140 & 2.16 & .619 & & \\
\hline & $23-27$ years & 95 & 2.02 & .545 & & \\
\hline & $28-32$ years & 54 & 2.00 & .476 & 3.153 & $.025^{*}$ \\
\hline & $33+$ years & 65 & 1.92 & .568 & & \\
\hline
\end{tabular}

$* \mathrm{p}<0.05 * * \mathrm{p}<0.01$

Table 7 illustrates the mean (M), standard deviation (SD), T-test and ANOVA of the use of smartphones to perform 16 nonlearning activities by students. When the frequently of reported non-learning activities were compared across the different categories of each of the eight socio-demographic variables, the following were found:

- Using a smartphone to do five non-learning activities varied according to student gender. Male students used their smartphones for reading documents $(\mathrm{M}=2.51, \mathrm{t}=2.556, \mathrm{p}=0.011)$, making phone calls $(\mathrm{M}=2.89, \mathrm{t}=2.307, \mathrm{p}=$ $0.022)$, and checking their emails $(M=2.69, \mathrm{t}=1.990, \mathrm{p}=0.047)$ more than females. However, female students used their smartphones for taking pictures $(\mathrm{M}=2.81, \mathrm{t}=-2.596, \mathrm{p}=0.01)$ and as a watch $(\mathrm{M}=2.83, \mathrm{t}=-2.331, \mathrm{p}=0.020)$ more than males. The use of a smartphone to do other non-learning activities did not vary according to student gender.

- Using a smartphone to do three non-learning activities varied according to students' marital status. Single students used their smartphones for listening to music $(\mathrm{M}=2.58, \mathrm{t}=4.151, \mathrm{p}=0.000)$, watching movies $(\mathrm{M}=2.14, \mathrm{t}=2.446$, $\mathrm{p}=0.015)$ and downloading applications $(\mathrm{M}=2.68, \mathrm{t}=2.409, \mathrm{p}=0.017)$ more than married students. The use of a smartphone to do other non-learning activities did not vary according to students' marital status.

- Using a smartphone to do two non-learning activities varied according to students' nationality. Non-Kuwaiti students used their smartphones for listening to music $(\mathrm{M}=2.61, \mathrm{t}=-3.289, \mathrm{p}=0.001)$ and checking and/or updating their profiles on social networking sites $(\mathrm{M}=2.72, \mathrm{t}=-2.880, \mathrm{p}=0.004)$ more than Kuwaiti students. The use of a smartphone to do other non-learning activities did not vary according to students' nationality.

- Using Smartphone to do two non-learning activities varied according to the Smartphone brand. Students who had iPhones used these phones for taking pictures $(\mathrm{M}=2.81, \mathrm{t}=2.177, \mathrm{p}=0.030)$ and chatting using social networking sites $(M=2.84, t=2.851, p=0.005)$ more than students who had Samsung phones. Using Smartphone to do other nonlearning activities did not vary according to the Smartphone brand.

- Using a smartphone to do four non-learning activities varied according to using the Smartphone for the first time. Students who had their smartphones for five years or more used these phones for reading documents $(\mathrm{M}=2.45, \mathrm{t}=$ $-2.046, \mathrm{p}=0.041)$, checking website pages $(\mathrm{M}=2.78, \mathrm{t}=-2.019, \mathrm{p}=0.044)$, and watching movies $(\mathrm{M}=2.13, \mathrm{t}=$ $2.081, \mathrm{p}=0.038)$ and TV $(\mathrm{M}=2.13, \mathrm{t}=-2.244, \mathrm{p}=0.025)$ more than those who had had their smartphones for four 
years or less. The use of a smartphone to do other non-learning activities did not vary according to using the smartphone for the first time.

- Using a smartphone to do five non-learning activities varied according to students' age ranges. Students who were aged between 18 and 22 used their smartphones for downloading applications $(\mathrm{M}=2.74, \mathrm{~F}=4.719, \mathrm{p}=0.003)$, listening to music $(\mathrm{M}=2.79, \mathrm{~F}=19.954, \mathrm{p}=0.000)$, watching movies $(\mathrm{M}=2.26, \mathrm{~F}=6.617, \mathrm{p}=0.000)$, and checking and/or updating their profile on social networking sites $(\mathrm{M}=2.74, \mathrm{~F}=3.149, \mathrm{p}=0.025)$ more than those who were in other age groups. However, students who were 33 years old and above used their smartphones for making phone calls $(\mathrm{M}=2.92, \mathrm{~F}=2.696, \mathrm{p}=0.046)$ more than those who were in other age groups. The use of a smartphone to do other non-learning activities did not vary according to students' age groups.

Table 7

The mean (M), standard deviation (SD), T-test and ANOVA of the use of smartphones to do non-learning activities by student

\begin{tabular}{|c|c|c|c|c|c|c|}
\hline $\begin{array}{l}\text { How often do you use your smartphone to do the following gen- } \\
\text { eral (non-learning) activities? }\end{array}$ & Background variables & $\mathbf{N}$ & Mean & SD & $\mathbf{t}$ & Sig. (2-tailed) \\
\hline \multirow[t]{4}{*}{ Listening to the music } & Kuwaiti & 163 & 2.37 & .777 & \multirow{2}{*}{-3.289} & \multirow{2}{*}{$.001 * *$} \\
\hline & Non-Kuwaiti & 201 & 2.61 & .608 & & \\
\hline & Single & 267 & 2.58 & .657 & \multirow[b]{2}{*}{4.151} & \multirow{2}{*}{$.000 * *$} \\
\hline & Married & 83 & 2.23 & .754 & & \\
\hline \multirow[t]{4}{*}{ Reading documents } & Male & 136 & 2.51 & .571 & \multirow[b]{2}{*}{2.556} & \multirow[b]{2}{*}{$.011 *$} \\
\hline & Female & 234 & 2.34 & 617 & & \\
\hline & Four years and less & 108 & 2.31 & .648 & \multirow{2}{*}{-2.046} & \multirow{2}{*}{$.041 *$} \\
\hline & Five years and more & 262 & 2.45 & .583 & & \\
\hline \multirow[t]{4}{*}{ Taking pictures } & Male & 136 & 2.68 & .512 & \multirow{2}{*}{-2.596} & \multirow{2}{*}{$.010^{*}$} \\
\hline & Female & 234 & 2.81 & .423 & & \\
\hline & iPhone & 216 & 2.81 & .413 & \multirow{2}{*}{2.177} & \multirow{2}{*}{$.030 *$} \\
\hline & Samsung & 110 & 2.70 & .517 & & \\
\hline \multirow[t]{4}{*}{ Watching movies } & Four years and less & 108 & 1.94 & .771 & \multirow{2}{*}{-2.081} & \multirow{2}{*}{$.038^{*}$} \\
\hline & Five years and more & 262 & 2.13 & .782 & & \\
\hline & Single & 267 & 2.14 & .762 & \multirow{2}{*}{2.446} & \\
\hline & Married & 83 & 1.90 & .821 & & $.015^{*}$ \\
\hline Making phone calls & Male & 136 & 2.89 & .314 & & \\
\hline & Female & 234 & 2.79 & .415 & 2.307 & $.022^{*}$ \\
\hline Checking email & Male & 136 & 2.69 & .495 & & \\
\hline & Female & 234 & 2.57 & .583 & 1.990 & $.047^{*}$ \\
\hline Use as a watch & Male & 136 & 2.72 & .482 & & \\
\hline & Female & 234 & 2.83 & .399 & -2.331 & $.020^{*}$ \\
\hline Downloading applications & Single & 267 & 2.68 & .499 & & \\
\hline & Married & 83 & 2.52 & .612 & 2.409 & $.017^{*}$ \\
\hline Chatting using social networking sites & iPhone & 216 & 2.84 & .394 & & \\
\hline & Samsung & 110 & 2.69 & .520 & 2.851 & $.005^{* *}$ \\
\hline Checking websites pages & Four years and less & 108 & 2.68 & .508 & & \\
\hline & Five years and more & 262 & 2.78 & .416 & -2.019 & $.044^{*}$ \\
\hline Watching TV & Four years and less & 108 & 1.94 & .734 & & \\
\hline & Five years and more & 262 & 2.13 & .738 & -2.244 & $.025^{*}$ \\
\hline Checking and/or updating your profile on social networking sites & Kuwaiti & 163 & 2.55 & .640 & & \\
\hline & Non-Kuwaiti & 201 & 2.72 & .522 & -2.880 & $.004^{2 * \pi}$ \\
\hline & & & & & $\mathbf{F}$ & Sig. \\
\hline Making phone calls & $18-22$ years & 139 & 2.77 & .439 & & \\
\hline & $23-27$ years & 97 & 2.86 & .353 & & \\
\hline & $28-32$ years & 56 & 2.80 & .401 & 2.696 & $.046^{*}$ \\
\hline & $33+$ years & 66 & 2.92 & .267 & & \\
\hline Downloading applications & $18-22$ years & 139 & 2.74 & .471 & & \\
\hline & 23-27 years & 97 & 2.66 & .476 & & \\
\hline & $28-32$ years & 56 & 2.55 & .601 & 4.719 & $.003^{* *}$ \\
\hline & $33+$ years & 66 & 2.47 & .588 & & \\
\hline Listening to the music & $18-22$ years & 139 & 2.79 & .458 & & \\
\hline & $23-27$ years & 97 & 2.39 & .701 & & \\
\hline & $28-32$ years & 56 & 2.50 & .714 & 19.954 & $.000 \%$ \\
\hline & $33+$ years & 66 & 2.08 & .810 & & \\
\hline Watching movies & $18-22$ years & 139 & 2.26 & .765 & & \\
\hline & 23-27 years & 97 & 2.08 & .717 & & \\
\hline & $28-32$ years & 56 & 2.00 & .786 & 6.617 & $.000 * *$ \\
\hline & $33+$ years & 66 & 1.76 & .824 & & \\
\hline Checking and/or updating your profile on social networking sites & $18-22$ years & 139 & 2.74 & .501 & & \\
\hline & $23-27$ years & 97 & 2.62 & .636 & & \\
\hline & $28-32$ years & 56 & 2.59 & .596 & 3.149 & $.025^{*}$ \\
\hline & $33+$ years & 66 & 2.48 & .638 & & \\
\hline
\end{tabular}

$* \mathrm{p}<0.05 * * \mathrm{p}<0.01$

Table 8 illustrates the mean (M), standard deviation (SD), T-test and ANOVA of the use of smartphones to do 18 learning activities by students. When the frequently reported learning activities were compared across the different categories of each of the eight socio-demographic variables, the following were found:

- Using a smartphone to do nine learning activities varied according to students' gender. Female students used their smartphones for registering on courses $(M=2.44, t=-3.791, p=0.000)$, sending emails to tutors $(M=2.15, t=-2.291, p$ $=0.023)$, using blackboard (LMS) $(\mathrm{M}=2.59, \mathrm{t}=-4.905, \mathrm{p}=0.000)$, logging in to the university portal $(\mathrm{M}=2.65, \mathrm{t}=-$ 2.787, $\mathrm{p}=0.006)$, downloading class material $(\mathrm{M}=2.47, \mathrm{t}=-3.412, \mathrm{p}=0.001)$, recording a class lecture $(\mathrm{M}=1.63, \mathrm{t}=$ - 
3.328, $\mathrm{p}=0.001)$, using SIS $(\mathrm{M}=2.44, \mathrm{t}=-3.554, \mathrm{p}=0.000)$, checking exam schedules $(\mathrm{M}=2.77, \mathrm{t}=-2.034, \mathrm{p}=0.043)$, and using a smartphone to participate in class learning groups $(\mathrm{M}=2.47, \mathrm{t}=-2.034, \mathrm{p}=0.004)$ more than males. The use of a smartphone to do other learning activities did not vary according to students' gender.

- Using a smartphone to do three learning activities varied according to students' major/subject. Business students used their smartphones for processing students relating services transactions $(\mathrm{M}=2.25, \mathrm{t}=2.925, \mathrm{p}=0.004)$, registering courses $(\mathrm{M}$ $=2.39, \mathrm{t}=2.719, \mathrm{p}=0.007)$, and checking grades $(\mathrm{M}=2.73, \mathrm{t}=3.449, \mathrm{p}=0.001)$ more than non-business students. The use of a smartphone to do other learning activities did not vary according to students' major/subject.

- Using a smartphone to do two learning activities varied according to students' nationality. Kuwaiti students used their smartphones for processing students relating services transactions $(\mathrm{M}=2.28, \mathrm{t}=2.081, \mathrm{p}=0.038)$ and payment of fees $(\mathrm{M}=2.24, \mathrm{t}=2.339, \mathrm{p}=0.02)$ more than non-Kuwaiti students. The use of a smartphone to do other learning activities did not vary according to students' nationality.

- Using a smartphone to do one learning activities varied according to the smartphone brand. Students who had iPhones used them for taking photos of a class presentation $(\mathrm{M}=2.13, \mathrm{t}=2.436, \mathrm{p}=0.015)$ more than students who had Samsung phones. The use of a smartphone to do other learning activities did not vary according to the Smartphone brand.

- Using a smartphone to do four learning activities varied according to using the smartphone for the first time. Students who had had their smartphones for five years or more used these phones for processing students relating services transactions $(\mathrm{M}=2.28, \mathrm{t}=-3.720-, \mathrm{p}=0.000)$, sending emails to tutors $(\mathrm{M}=2.14, \mathrm{t}=-2.386, \mathrm{p}=0.018)$, using blackboard (LMS) (M $=2.52, \mathrm{t}=-2.312, \mathrm{p}=0.021)$, and using e-library resources $(\mathrm{M}=1.83, \mathrm{t}=-2.815, \mathrm{p}=0.005)$ more than those who had had their smartphones for four years or less. The use of a smartphone to do other learning activities did not vary according to using the phone for the first time.

- Using a smartphone to do two learning activities varied according to students' age groups. Students who were 33 years old and above used their smartphones for processing students relating services transactions $(\mathrm{M}=2.39, \mathrm{~F}=3.549, \mathrm{p}=$ $0.015)$ and payment of fees $(\mathrm{M}=2.31, \mathrm{~F}=2.704, \mathrm{p}=0.045)$ more than those who were in other age groups. The use of a smartphone to do other learning activities did not vary according to students' age groups.

- Using a smartphone to do five learning activities varied according to students' study level. Students who were in their $4^{\text {th }}$ year and above used their smartphones for logging in to the university portal $(\mathrm{M}=2.66, \mathrm{~F}=2.812, \mathrm{p}=0.039)$, using blackboard (LMS) $(\mathrm{M}=2.55, \mathrm{~F}=3.701, \mathrm{p}=0.012)$, and registering courses $(\mathrm{M}=2.43, \mathrm{~F}=2.895, \mathrm{p}=0.035)$ more than those in other years. However, students who were in $3^{\text {rd }}$ year used their smartphones for recording class lectures $(\mathrm{M}=$ $1.70, \mathrm{~F}=3.599, \mathrm{p}=0.014)$ more than those in other years, and students who were in their $1^{\text {st }}$ year used their smartphones for taking notes in classrooms $(\mathrm{M}=2.04, \mathrm{~F}=4.066, \mathrm{p}=0.007)$ more than those in other years. The use of a smartphone to do other learning activities did not vary according to students' study levels.

Table 8

The mean (M), standard deviation (SD), T-test and ANOVA of the use of Smartphone to perform learning activities by student

\begin{tabular}{|c|c|c|c|c|c|c|}
\hline $\begin{array}{l}\text { How often do you use your smartphone to do the following learn- } \\
\text { ing activities? }\end{array}$ & Background variables & $\mathbf{N}$ & Mean & SD & $\mathbf{t}$ & Sig. (2-tailed) \\
\hline \multirow[t]{6}{*}{ processing students relating services transactions } & Kuwaiti & 162 & 2.28 & .700 & \multirow{2}{*}{2.081} & \multirow{2}{*}{$.038 *$} \\
\hline & Non-Kuwaiti & 202 & 2.12 & .753 & & \\
\hline & Business & 292 & 2.25 & .714 & \multirow[t]{2}{*}{2.925} & \multirow[t]{2}{*}{$.004 * *$} \\
\hline & Non-Business & 77 & 1.97 & .778 & & \\
\hline & Four years and less & 108 & 1.97 & .716 & \multirow[t]{2}{*}{-3.720} & \multirow[t]{2}{*}{$.000 * *$} \\
\hline & Five years and more & 261 & 2.28 & .725 & & \\
\hline \multirow[t]{4}{*}{ registering for courses } & Male & 135 & 2.14 & .745 & \multirow[t]{2}{*}{-3.791} & \multirow[t]{2}{*}{$.000 * *$} \\
\hline & Female & 234 & 2.44 & .723 & & \\
\hline & Business & 292 & 2.39 & .716 & \multirow[t]{2}{*}{2.719} & \multirow[t]{2}{*}{$.007 * *$} \\
\hline & Non-Business & 77 & 2.13 & .817 & & \\
\hline \multirow[t]{4}{*}{ sending emails to tutors } & Male & 135 & 1.97 & .680 & \multirow[t]{2}{*}{-2.291} & \multirow[t]{2}{*}{$.023^{*}$} \\
\hline & Female & 235 & 2.15 & .745 & & \\
\hline & Four years and less & 108 & 1.94 & .734 & \multirow[t]{2}{*}{-2.386} & \multirow[t]{2}{*}{$.018 *$} \\
\hline & Five years and more & 262 & 2.14 & .716 & & \\
\hline \multirow[t]{4}{*}{ using blackboard (LMS) } & Male & 136 & 2.26 & .680 & \multirow[t]{2}{*}{-4.905} & \multirow[t]{2}{*}{$.000^{* *}$} \\
\hline & Female & 235 & 2.59 & .566 & & \\
\hline & Four years and less & 108 & 2.35 & .660 & \multirow[t]{2}{*}{-2.312} & \multirow[t]{2}{*}{$.021 *$} \\
\hline & Five years and more & 263 & 2.52 & .611 & & \\
\hline \multirow[t]{2}{*}{ login to the university portal } & Male & 136 & 2.50 & .531 & \multirow[t]{2}{*}{-2.787} & \multirow[t]{2}{*}{$.006 * *$} \\
\hline & Female & 235 & 2.65 & .487 & & \\
\hline \multirow[t]{2}{*}{ downloading class material } & Male & 135 & 2.21 & .754 & \multirow[t]{2}{*}{-3.412} & \multirow[t]{2}{*}{$.001 * *$} \\
\hline & Female & 233 & 2.47 & .676 & & \\
\hline recording a class lecture & Male & 134 & 1.39 & .600 & -3.328 & $.001 * *$ \\
\hline & Female & 234 & 1.63 & .719 & & \\
\hline using SIS & Male & 135 & 2.19 & .675 & -3.554 & $.000 * *$ \\
\hline & Female & 235 & 2.44 & .620 & & \\
\hline checking exam schedules & Male & 135 & 2.66 & .575 & -2.034 & $.043 *$ \\
\hline & Female & 234 & 2.77 & .452 & & \\
\hline using it to participate in the class learning groups & Male & 135 & 2.25 & .720 & -2.885 & $.004 * *$ \\
\hline & Female & 234 & 2.47 & .688 & & \\
\hline payment of fees & Kuwaiti & 160 & 2.24 & .791 & 2320 & $020 *$ \\
\hline & Non-Kuwaiti & 201 & 2.04 & .848 & 2.339 & $.020^{*}$ \\
\hline checking grades & Business & 292 & 2.73 & .531 & 3.449 & $.001 * *$ \\
\hline & Non-Business & 77 & 2.48 & .641 & & \\
\hline
\end{tabular}


Table 8

The mean (M), standard deviation (SD), T-test and ANOVA of the use of Smartphone to perform learning activities by student

\begin{tabular}{|c|c|c|c|c|c|c|}
\hline $\begin{array}{l}\text { How often do you use your smartphone to do the following learn- } \\
\text { ing activities? }\end{array}$ & Background variables & $\mathbf{N}$ & Mean & SD & $\mathbf{t}$ & Sig. (2-tailed) \\
\hline \multirow[t]{2}{*}{ using e-library resources } & Four years and less & 108 & 1.60 & .669 & \multirow[t]{2}{*}{$-2.815-$} & \multirow[t]{2}{*}{$.005^{* *}$} \\
\hline & Five years and more & 261 & 1.83 & .730 & & \\
\hline \multirow[t]{3}{*}{ taking photos of a class presentation } & iPhone & 214 & 2.13 & .658 & \multirow[t]{2}{*}{2.436} & \multirow[t]{2}{*}{$.015^{*}$} \\
\hline & Samsung & 111 & 1.95 & .630 & & \\
\hline & & & & & $\mathbf{F}$ & Sig. \\
\hline \multirow[t]{4}{*}{ processing students relating services transactions } & $18-22$ years & 139 & 2.06 & .740 & \multirow{4}{*}{3.549} & \multirow{4}{*}{$.015^{*}$} \\
\hline & 23-27 years & 96 & 2.25 & .725 & & \\
\hline & 28-32 years & 56 & 2.16 & .682 & & \\
\hline & $33+$ years & 66 & 2.39 & .721 & & \\
\hline \multirow[t]{4}{*}{ payment of fees } & $18-22$ years & 138 & 1.98 & .850 & \multirow{4}{*}{2.704} & \multirow{4}{*}{$.045^{*}$} \\
\hline & 23-27 years & 96 & 2.19 & .812 & & \\
\hline & $28-32$ years & 55 & 2.07 & .858 & & \\
\hline & $33+$ years & 65 & 2.31 & .789 & & \\
\hline \multirow[t]{4}{*}{ login to the university portal } & 1st year & 28 & 2.36 & .559 & \multirow{4}{*}{2.812} & \multirow{4}{*}{$.039 *$} \\
\hline & 2nd year & 80 & 2.56 & .524 & & \\
\hline & 3 rd year & 121 & 2.61 & .506 & & \\
\hline & 4th year \& above & 114 & 2.66 & .477 & & \\
\hline \multirow[t]{4}{*}{ using blackboard (LMS) } & 1st year & 28 & 2.18 & .723 & \multirow{4}{*}{3.701} & \multirow{4}{*}{$.012 *$} \\
\hline & 2nd year & 80 & 2.38 & .663 & & \\
\hline & 3rd year & 121 & 2.53 & .593 & & \\
\hline & 4th year \& above & 114 & 2.55 & .596 & & \\
\hline \multirow[t]{4}{*}{ taking notes in a classroom } & 1st year & 28 & 2.04 & .793 & \multirow{4}{*}{4.066} & \multirow{4}{*}{$.007 * *$} \\
\hline & 2nd year & 79 & 1.65 & .699 & & \\
\hline & 3rd year & 121 & 1.87 & .741 & & \\
\hline & 4th year \& above & 114 & 2.01 & .793 & & \\
\hline \multirow[t]{4}{*}{ recording a class lecture } & 1st year & 28 & 1.39 & .629 & \multirow{4}{*}{3.599} & \multirow{4}{*}{$.014^{*}$} \\
\hline & 2nd year & 79 & 1.41 & .631 & & \\
\hline & 3rd year & 120 & 1.70 & .729 & & \\
\hline & 4th year \& above & 113 & 1.57 & .680 & & \\
\hline \multirow[t]{4}{*}{ registering courses } & 1st year & 27 & 2.19 & .786 & \multirow{4}{*}{2.895} & \multirow{4}{*}{$.035^{*}$} \\
\hline & 2nd year & 79 & 2.14 & .780 & & \\
\hline & 3rd year & 121 & 2.36 & .742 & & \\
\hline & 4 th year \& above & 114 & 2.43 & .678 & & \\
\hline
\end{tabular}

- $\quad * \mathrm{p}<0.05 * * \mathrm{p}<0.01$

Table 9 illustrates the mean (M), standard deviation (SD), T-test and ANOVA of the importance of various reasons for owning/using smartphones by students. The following scale is used to facilitate reporting the results:

- The reason for owning/using a smartphone was important: calculated mean $(M \geq 3.6)$.

- The reason for owning/using a smartphone was moderately important: calculated mean $(2.1>M<3.6)$.

- The reason for owning/using a smartphone was not important: calculated mean $(M \leq 2.1)$.

As shown in Table 9, there were significant differences among students in relation to the importance of the reasons for owning/using smartphones as follows:

- Safety $(\mathrm{M}=3.82, \mathrm{t}=-2.764, \mathrm{p}=0.006)$ and fashion $(\mathrm{M}=3.85, \mathrm{t}=-2.304, \mathrm{p}=0.022)$ were important reasons for owning/using smartphones amongst female students, at the same time they were moderately important reasons for male students. There were no gender differences in the importance of other reasons.

- Business students owned/used their smartphones for fashion and social networking reasons more than non-business students. However, the level of importance was different for each of these two reasons. Fashion $(\mathrm{M}=2.81, \mathrm{t}=2.227, \mathrm{p}$ $=0.027)$ was moderately important, though social networking $(\mathrm{M}=4.46, \mathrm{t}=2.032, \mathrm{p}=0.043)$ was important. There were no differences in the importance of other reasons.

- Students who had had smartphones for five years or more owned/used their smartphones for safety, privacy, fashion, social status symbols, and freedom more than those who had had smartphones for four years or less. However, the level of importance was different for each of these reasons. Fashion $(\mathrm{M}=2.85, \mathrm{t}=-2.590, \mathrm{p}=0.01)$, social status symbol $(\mathrm{M}=3.24, \mathrm{t}=-3.393, \mathrm{p}=0.001)$ and freedom $(\mathrm{M}=3.21, \mathrm{t}=-1.977, \mathrm{p}=0.049)$ were moderately important, and privacy $(\mathrm{M}=4.10, \mathrm{t}=-3.363, \mathrm{p}=0.001)$ was important. Safety $(\mathrm{M}=3.79, \mathrm{t}=-2.455, \mathrm{p}=0.015)$, was an important reason for owning/using smartphones for students who had had their phones for five years or more, at the same time they were moderately important reasons for those who had had their phones for four years or less. There were no differences in the importance of other reasons.

- Kuwaiti students owned/used their smartphones for safety $(\mathrm{M}=3.82, \mathrm{t}=2.029, \mathrm{p}=0.043)$ reasons more than nonKuwaitis $(\mathrm{M}=3.55)$. However, this reason was moderately important to both groups. There were no differences in the importance of other reasons.

- Students who had iPhones owned/used them for privacy $(\mathrm{M}=4.12, \mathrm{t}=2.165, \mathrm{p}=0.031)$ reasons more than those who had Samsung phones $(M=3.84)$. However, this reason was important to both groups. There were no differences in the importance of other reasons.

- $\quad$ Students in the 28 to 32 age group owned/used their smartphones for reasons of fashion $(\mathrm{M}=3.09, \mathrm{t}=3.984, \mathrm{p}=$ $0.008)$, loneliness $(\mathrm{M}=2.96, \mathrm{t}=3.803, \mathrm{p}=0.01)$ and freedom $(\mathrm{M}=3.57, \mathrm{t}=2.893, \mathrm{p}=0.035)$ more than those of other 
age groups. However, these three reasons were moderately important to all groups. There were no differences in the importance of other reasons.

Table 9

The mean (M), standard deviation (SD), T-test and ANOVA of the importance of various reasons for owning/using smartphones by students

\begin{tabular}{|c|c|c|c|c|c|c|}
\hline $\begin{array}{l}\text { How important are the following reasons for owning/us- } \\
\text { ing a smartphone? }\end{array}$ & Background variables & $\mathbf{N}$ & Mean & SD & $\mathbf{t}$ & $\begin{array}{l}\text { Sig. (2- } \\
\text { tailed) }\end{array}$ \\
\hline \multirow{6}{*}{ Safety } & Male & 136 & 3.45 & 1.304 & \multirow{2}{*}{$-2.764-$} & \multirow{2}{*}{$.006 * *$} \\
\hline & Female & 235 & 3.82 & 1.220 & & \\
\hline & Kuwaiti & 162 & 3.82 & 1.142 & \multirow{2}{*}{2.029} & \multirow{2}{*}{$.043 *$} \\
\hline & Non-Kuwaiti & 203 & 3.55 & 1.346 & & \\
\hline & Four years \& less & 108 & 3.44 & 1.248 & \multirow{2}{*}{$-2.455-$} & \multirow{2}{*}{$.015 *$} \\
\hline & Five years $\&$ more & 263 & 3.79 & 1.257 & & \\
\hline \multirow{6}{*}{ Fashion } & Male & 136 & 2.49 & 1.440 & \multirow{2}{*}{$-2.304-$} & \multirow{2}{*}{$.022 *$} \\
\hline & Female & 234 & 2.85 & 1.460 & & \\
\hline & Business & 293 & 2.81 & 1.478 & & \\
\hline & Non-Business & 77 & 2.39 & 1.378 & 2.227 & $.027^{\circ}$ \\
\hline & Four years \& less & 108 & 2.42 & 1.326 & & \\
\hline & Five years $\&$ more & 262 & 2.85 & 1.503 & $-2.590-$ & $.010 \%$ \\
\hline \multirow{4}{*}{ Privacy } & Four years \& less & 108 & 3.65 & 1.263 & \multirow{2}{*}{$-3.363-$} & \multirow{2}{*}{$.001 * *$} \\
\hline & Five years \& more & 262 & 4.10 & 1.148 & & \\
\hline & iPhone & 216 & 4.12 & 1.036 & & \\
\hline & Samsung & 111 & 3.84 & 1.262 & 2.165 & $.031^{*}$ \\
\hline \multirow[t]{2}{*}{ Social networking } & Business & 294 & 4.46 & .836 & \multirow{2}{*}{2.032} & \multirow{2}{*}{$.043 *$} \\
\hline & Non-Business & 77 & 4.23 & .916 & & \\
\hline \multirow[t]{2}{*}{ Social status symbol } & Four years \& less & 108 & 2.71 & 1.361 & \multirow{2}{*}{$-3.393-$} & \multirow{2}{*}{$.001 * *$} \\
\hline & Five years $\&$ more & 261 & 3.24 & 1.361 & & \\
\hline \multirow[t]{3}{*}{ Freedom } & Four years and less & 108 & 2.90 & 1.420 & \multirow{2}{*}{$-1.977-$} & \multirow{2}{*}{$.049 *$} \\
\hline & Five years and more & 261 & 3.21 & 1.390 & & \\
\hline & & & & & $\mathbf{F}$ & Sig. \\
\hline \multirow{4}{*}{ Fashion } & 18-22 years & 140 & 2.81 & 1.462 & \multirow{4}{*}{3.984} & \multirow{4}{*}{$.008 * *$} \\
\hline & $23-27$ years & 97 & 2.69 & 1.570 & & \\
\hline & 28-32 years & 56 & 3.09 & 1.366 & & \\
\hline & $33+$ years & 66 & 2.23 & 1.275 & & \\
\hline \multirow{4}{*}{ Loneliness } & $18-22$ years & 140 & 2.64 & 1.440 & \multirow{4}{*}{3.803} & \multirow{4}{*}{$.010 * *$} \\
\hline & 23-27 years & 97 & 2.30 & 1.308 & & \\
\hline & 28-32 years & 56 & 2.96 & 1.427 & & \\
\hline & $33+$ years & 65 & 2.26 & 1.395 & & \\
\hline & $18-22$ years & 140 & 3.12 & 1.406 & & \\
\hline Freedom & 23-27 years & 97 & 2.94 & 1.383 & 2893 & \\
\hline Freedom & 28-32 years & 56 & 3.57 & 1.248 & 2.893 & $.035^{\circ}$ \\
\hline & $33+$ years & 65 & 2.94 & 1.467 & & \\
\hline
\end{tabular}

- $\quad * \mathrm{p}<0.05 * * \mathrm{p}<0.01$

\section{Discussion}

The findings of this research demonstrate that almost all students own/use a smartphone. Students mostly used iPhones and Samsung, and the majority of them started using their smartphones for the first time five years or more ago. Also, students always used their smartphones at their homes whilst they sometimes used these phones in several other places such as recreational places, university, transportation, and when walking; they almost never used their smartphones when driving. This is echoed by the remarks made by Kim et al. (2015) and equally van Deursen et al. (2015) who argued that the opportunity to gain internet access worldwide through various techniques may cause students to engage in various activities. Moreover, students always used their smartphones to do several non-learning activities such as making phone calls, using it as a watch and as an alarm clock, chatting using social networking sites, taking pictures, browsing the internet, checking website pages, checking and/or updating their profiles on social networking sites, downloading applications, checking email, recording video, sending text messages, listening to music and reading documents, and they sometimes used their smartphones to watch TV and movies. This is further supported by the findings of Blanchard et al. (2012), who found that engaging in non-learning activities such as shopping and social network-based communication may in fact negatively influence students' behaviour.

Furthermore, students always used their smartphones to perform a number of learning activities such as checking exam schedules, checking class timetables, checking grades, logging in to the university portal, using blackboard (LMS), using it to participate in the class learning groups, downloading class material, using SIS, reading tutors' announcements, and registering for courses. They also sometimes used their smartphones to perform a number of learning activities such as processing students relating services transactions, payment of fees, sending emails to tutors, taking photos of class presentations, uploading class assignments, taking notes in classrooms, and using e-library resources, and they never used their smartphones to record class lectures. These findings are similar to the findings for Western societies which demonstrates that smartphones are extensively used in their contexts for academic success as well as for other leaning purposes (Mok et al., 2014; Kibona and 
Mgaya, 2015; Olufadi, 2015; Lee et al., 2015). In addition, social networking, learning, privacy, and safety were important reasons for students owning/using smartphones, however, freedom, social status symbol, fashion, and loneliness were moderately important reasons for students owning/using smartphones. In terms of the demographic and social differences in smartphone usage among students, the findings reveal that at least one place in which students used their smartphones varies according to at least one of six socio-demographic variables (i.e., gender, marital status, nationality, major/subject, use for the first time, and age group). In contrast, two socio-demographic variables had no effect on any of the different places (i.e., the brand of smartphone and level of study).

- Male or married students sometimes used their smartphones when driving more than female or single students, who never used them for this purpose.

- Business students sometimes used their smartphones in recreational places more than non-business students.

- Non-Kuwaiti students always used their smartphones at home, sometimes at university and on transportation more than Kuwaiti students. However, Kuwaiti students sometimes used their smartphones when driving more than nonKuwaitis, who never used them for this purpose.

- Students who had had their smartphones for five years or more sometimes used these phones when driving and walking and in recreational places more than those who had had their Smartphones for four years or less.

- Students who were aged between 18 and 22 always used their smartphones at home, sometimes at university and on transportation more than those in other age groups. However, students aged between 28 and 32 sometimes used their smartphones when driving more than those in other age groups.

The findings also reflect that at least one non-learning activity that students perform using their Smartphones varies according to at least one of six socio-demographic variables (i.e., gender, marital status, nationality, brand of smartphone, using it for the first time, and age group). By contrast, two socio-demographic variables have no effect on any of the non-learning activities (i.e., major/subject and level of study).

- Male students used their smartphones for reading documents, making phone calls, and checking their emails more than females. However, female students used their smartphones for taking pictures and as a watch more than males.

- Single students used their smartphones for listening to music, watching movies and downloading applications more than married students.

- Non-Kuwaiti students used their Smartphones for listening to music and checking and/or updating their profiles on social networking sites more than Kuwaiti students.

- Students who had iPhones used them for taking pictures and chatting using social networking sites more than students who had Samsung phones.

- Students who had had their smartphones for five years or more used these phones for reading documents, checking website pages, and watching movies and TV more than those who had had their smartphones for four years or less.

- Students who were aged between 18 and 22 used their smartphones for downloading applications, listening to music, watching movies, and checking and/or updating their profiles on social networking sites more than those in other age groups. However, students who were 33 years old and above used their smartphones for making phone calls more than those who were in other age groups.

Moreover, the findings prove that at least one non-learning activity that students do using their smartphones varies according to at least one of seven socio-demographic variables (i.e., gender, major, nationality, brand of smartphone, using it for the first time, age group and level of study). In contrast, one demographic variable had no effect on any of the learning activities (i.e., marital status,).

- Female students used their smartphones for registering courses, sending emails to tutors, using blackboard (LMS), logging in to the university portal, downloading class material, recording a class lecture, using SIS, checking exam schedules, and using it to participate in class learning groups more than males.

- Business students used their smartphones for processing students relating services transactions, registering for courses, and checking grades more than non-business students.

- Kuwaiti students used their smartphones for processing students relating services transactions and payment of fees more than non-Kuwaiti students.

- Students who had iPhones used them for taking photos of class presentations more than students who had Samsung phones.

- Students who had had their smartphones for five years or more used these phones for processing students relating services transactions, sending emails to tutors, using blackboard (LMS), and using e-library resources more than those who had had their smartphones for four years or less.

- Students who were 33 years old and above used their Smartphones for processing students relating services transactions and payment of fees more than those who were in other age groups.

- Students who were in their $4^{\text {th }}$ year of studies and above used their smartphones for logging in to the university portal, using blackboard (LMS), and registering for courses more than those in other years. However, students who were in their $3^{\text {rd }}$ year used their smartphones for recording class lectures more than those in other years, whilst students who were in their $1^{\text {st }}$ year used their smartphones for taking notes in classrooms more than those in other years. 
Furthermore, the findings show that at least one of six socio-demographic variables (i.e., gender, major, nationality, brand of smartphone, using it for the first time, and age group) had an effect on the importance of at least one of the reasons for owning/using smartphones. In contrast, two socio-demographic variables had no effect on the importance of any of the reasons for owning/using smartphones (i.e., marital status and level of study)

- Safety and fashion were important reasons for owning/using smartphones amongst female students and they were moderately important reasons for male students.

- Business students owned/used their smartphones for fashion (moderately important) and social networking (important) reasons more than non-business students.

- Students who had had smartphones for five years or more owned/used their smartphones for reasons of safety, privacy (important), fashion (moderately important), social status symbol (moderately important), and freedom (moderately important) more than those who had had smartphones for four years or less. Safety was important reason for owning/using a smartphone for students who had had these phones for five years or more and they were only moderately important reasons for those who had had their phones for four years or less.

- Kuwaiti students owned/used their smartphones for safety (moderately important) reasons more than non-Kuwaitis.

- Students who had iPhones owned/used them for privacy (important) reasons more than those who had Samsung phones.

- Students in the 28 to 32 year-old age group owned/used their smartphones for fashion, loneliness and freedom reasons more than those of other age groups. However, these three reasons were only moderately important.

However, the fact that the data collected for this study was limited to AOU university students should be taken into consideration. Investigating only university students might not wholly explain the use of smartphone-related behaviour in general.

\section{Conclusions and Implications}

Smartphones have considerable potential to make 'learning on the move' 'anytime, and anyplace' a realization. The dilemma apparent in this study is that there was a shortage of relevant studies concerning smartphone usage in Kuwait by people in general and the Kuwaiti youth in particular. The aim of this study was therefore twofold: (i) to explore the everyday use and roles of smartphones among university students in Kuwait; and (ii) to identify if there were any socio-demographic differences in smartphone usage among university students. A questionnaire that included 376 students was conducted in order to achieve the study objectives. The results showed that students always used their smartphones in their homes and sometimes in recreational places and on transportation, at university, and when walking. Also, they always used their smartphones to do fourteen non-learning activities, such as making phone calls, using it as a watch and as an alarm clock, and ten learning activities such as checking exam schedules, checking class timetables, and checking grades. Moreover, social networking, learning, privacy, and safety were important reasons for owning/using smartphones by students. Furthermore, the study found that at least one of eight socio-demographic variables had an effect on at least one pattern of smartphone usage. The results of this research therefore provide information that could improve the experience of blended learning and, indeed, how to integrate smartphones into this environment. In this regard, understanding students' smartphone usage for learning purposes could help universities to develop and provide information that may meet the learning needs of their students. This also could provide information on how to implement learning environments that help each student to learn in the best way possible, and to make the LMS more portable so that it can be run on smartphones as well. Moreover, this could provide tutors with recommendations on how to communicate with and support students to make optimal use of the smartphones that they have at their disposal for learning purposes. The results of this research also provide valuable information on the students' use of smartphones for non-learning purposes. This could help universities to communicate more effectively with students, and could also help them to develop regulations and policies that manage the behavioural-related issues of using the mobiles on its premises. On the other hand, the results could be useful for marketers, smartphone developers, and researchers. The research findings could motivate marketers and smartphone developers to further develop smartphone functionality so as to be more relevant to students. The research also provides a unique perspective of students' dependence on smartphones, which is not covered to any real extent in the Kuwait context in the literature.

\section{References}

Balakrishnan, V., \& Raj, R. (2012). Exploring the relationship between urbanized Malaysian youth and their mobile phones: A quantitative approach. Telematics and Informatics, 29(3), 263-272.

Blanchard, A., \& Henle, C. (2008). Correlates of different forms of cyberloafing: the role of norms and external locus of control. Computers in Human Behavior, 24(3), 1067-1084.

Böhmer, M., Hecht, B., Schöning, J., Krüger, A., \& Bauer, G. (2011). Falling asleep with Angry Birds, Facebook and Kindle: a large scale study on mobile application usage. In Proceedings of the 13th international conference on Human computer interaction with mobile devices and services (pp. 47-56). ACM.

Bryman, A. (2016). Social Research Method. $5^{\text {th }}$ ed., Oxford, Oxford University Press.

Carvalho, L., Sette, C., \& Ferrari, B. (2018). Problematic smartphone use relationship with pathological personality traits: Systematic review and meta-analysis. Cyberpsychology: Journal of Psychosocial Research on Cyberspace, 12(3), 1-20.

Cohen, H. (2011). 30 Social Media Definitions, available at: http://heidicohen.com/social-media-definition/.

Cui, Y., \& Roto, V. (2008). April. How people use the web on mobile devices. In Proceedings of the 17th international conference on World Wide Web (pp. 905-914). ACM. 
Demirci, K., Akgönül, M., \& Akpinar, A. (2015). Relationship of smartphone use severity with sleep quality, depression, and anxiety in university students. Journal of Behavioral Addictions, 4(2), 85-92.

Elhai, J., Dvorak, R., Levine, J., \& Hall, B. (2017). Problematic smartphone use: A conceptual overview and systematic review of relations with anxiety and depression psychopathology. Journal of Affective Disorders, 207, pp. 251-259.

Falaki, H., Mahajan, R., Kandula, S., Lymberopoulos, D., Govindan, R., \& Estrin, D. (2010). June. Diversity in smartphone usage. In Proceedings of the 8th international conference on Mobile systems, applications, and services (pp. 179-194). ACM.

Fu, H., Hopper, T., \& Sanford, K. (2018). New BC curriculum and communicating student learning in an age of assessment for learning. Alberta Journal of Educational Research, 64(3), 264-286.

Gökçearslan, Ş., Mumcu, F., Haşlaman, T., \& Çevik, Y. (2016). Modelling smartphone addiction: The role of smartphone usage, selfregulation, general self-efficacy and cyberloafing in university students. Computers in Human Behavior, 63, pp. 639-649.

Hadlington, L. (2015). Cognitive failures in daily life: exploring the link with Internet addiction and problematic mobile phone use. Computers in Human Behavior, 51, 75-81.

Hazzi, O., \& Maldaon, I. (2015). A pilot study: Vital methodological issues. Business: Theory and Practice, 16(1), 53-62.

Jung, S., Lee, N., Kang, K., Kim, K., \& Do, Y. (2016). The effect of smartphone usage time on posture and respiratory function. Journal of Physical Therapy Science, 28(1), 186-189.

Kibona, L., \& Mgaya, G. (2015). Smartphones' effects on academic performance of higher learning students. Journal of Multidisciplinary Engineering Science and Technology (JMEST), 2(4), 777-784.

Kim, K., Triana, M., Chung, K., and Oh, N. (2015). When do employees cyberloaf? An interactionist perspective examining personality. justice, and empowerment. Human Resource Management. 55(6), 1041-1058.

Kim, L., \& Altmann, J. (2013). Adapting Smartphones as Learning Technology in a Korean University. Journal of integrated Design and Process Science, 17(1), 5-16.

Lee, H., Ahn, H., Choi, S., \& Choi, W. (2014). The SAMS: smartphone addiction management system and verification. Journal of Medical Systems, 38(1), 1-10.

Lee, J., Cho, B., Kim, Y., \& Noh, J. (2015). Smartphone addiction in university students and its implication for learning. In Emerging issues in smart learning (pp. 297-305). Springer Berlin Heidelberg.

Lee, Y., Chang, C., Lin, Y., \& Cheng, Z. (2014). The dark side of smartphone usage: psychological traits, compulsive behavior and technostress. Computers in Human Behavior, 31, pp. 373-383.

Lopez-Fernandez, O. (2017). Short version of the Smartphone Addiction Scale adapted to Spanish and French: Towards a cross-cultural research in problematic mobile phone use. Addictive Behaviors, 64, pp.275-280.

Mohtar, N., Hassan, M., Hassan, M., \& Osman, M. (2013). The importance of smartphone's usage among Malaysian undergraduates. IOSR Journal of Humanities and Social Science, 14(3), 112-118.

Mok, J., Choi, S., Kim, D., Choi, J., Lee, J., Ahn, H., \& Song, W. (2014). Latent class analysis on internet and smartphone addiction in college students. Neuropsychiatric Disease and Treatment, 10, pp. 817-828.

Mukorera, S., \& Nyatanga, P. (2017). Students' Perceptions of Teaching and Learning Practices: A Principal Component Approach. Alberta Journal of Educational Research, 63(2), 120-138.

Murdock, K. (2013) Texting While Stressed: Implications for Students' Burnout, Sleep, and Well-Being. Psychology of Popular Media Culture, 2(4), 207-221.

Olufadi, Y. (2015). A configurational approach to the investigation of the multiple paths to success of students through mobile phone use behaviors. Computers and Education, 86, 84-104.

Oulasvirta, A., Rattenbury, T., Ma, L. and Raita, E. (2012). Habits make smartphone use more pervasive. Personal and Ubiquitous Computing, 16(1), 105-114

Park, C., \& Park, Y. (2014). The conceptual model on smartphone addiction among early childhood. International Journal of Social Science and Humanity, 2(4): 147-150.

Payne, K., Wharrad, H., \& Watts, K. (2012) Smartphone and medical related App use among medical students and junior doctors in the United Kingdom (UK): a regional survey. BMC Medical Informatics and Decision Making, 12(1), p. 121.

Roberts, J., Yaya, L., \& Manolis, C. (2014). The invisible addiction: cell-phone activities and addiction among male and female college students. Journal of Behavioral Addictions, 3(4), 254-265.

Samaha, M., \& Hawi, N. (2016) Relationships among smartphone addiction, stress, academic performance, and satisfaction with life. Computers in Human Behavior, 57, 321-325.

Saunders, M., Lewis, P., \& Thornhill, A. (2016). Research Methods for Business Students. 7th Edition, England, Pearson.

Thomee, S., Harenstam, A., \& Hagberg, M. (2011). Mobile phone use and stress, sleep disturbances, and symptoms of depression among young adults a prospective cohort study. BMC Public Health, 11(1), 66-76.

Uys, W., Mia, A., Jansen, G., Schyff, H., ..., \& Samsodie, Y. (2012). Smartphone Application Usage Amongst Students at a South African University, 1ST-Africa2012 Conference Proceedings, 1-11.

Van Deursen, A., Bolle, C., Hegner, S., \& Kommers, P. (2015). Modeling habitual and addictive smartphone behavior: The role of smartphone usage types, emotional intelligence, social stress, self-regulation, age, and gender. Computers in Human Behavior, 45, 411420.

Wolniewicz, C., Tiamiyu, M., Weeks, J., \& Elhai, J. (2018). Problematic smartphone use and relations with negative affect, fear of missing out, and fear of negative and positive evaluation. Psychiatry Research, 262, 618-623.

Yu, J., Kim, H., and Hay, I. (2013) Understanding adolescents' problematic internet use from a social/cognitive and addiction research framework. Computers in Human Behavior, 29(6), 2682-2689.

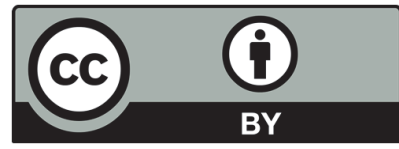

(C) 2020 by the authors; licensee Growing Science, Canada. This is an open access article distributed under the terms and conditions of the Creative Commons Attribution (CC-BY) license (http://creativecommons.org/licenses/by/4.0/). 